Article

\title{
No Tradeoff in Fiber Quality with Increased Cotton Yield Due to Outcross Pollination
}

\author{
Sarah Cusser ${ }^{1,2, *(D)}$ and Shalene Jha ${ }^{3, *(D)}$ \\ 1 Rubenstein School of Environment and Natural Resources, University of Vermont, Burlington, VT 05405, USA \\ 2 W. K. Kellogg Biological Station, Michigan State University, Hickory Corners, MI 49060, USA \\ 3 Department of Integrative Biology, University of Texas at Austin, 205 W 24th Street, \\ 401 Biological Laboratories, Austin, TX 78712, USA \\ * Correspondence: Sarah.Cusser@gmail.com (S.C.); sjha@austin.utexas.edu (S.J.)
}

Citation: Cusser, S.; Jha, S. No Tradeoff in Fiber Quality with Increased Cotton Yield Due to Outcross Pollination. Sustainability 2021, 13, 6079. https://doi.org/ $10.3390 /$ su13116079

Academic Editors: Luca Doro,

Abeyou W. Worqlul, Javier M. Osorio and Manyowa Norman Meki

Received: 7 April 2021

Accepted: 19 May 2021

Published: 28 May 2021

Publisher's Note: MDPI stays neutral with regard to jurisdictional claims in published maps and institutional affiliations.

Copyright: (c) 2021 by the authors. Licensee MDPI, Basel, Switzerland. This article is an open access article distributed under the terms and conditions of the Creative Commons Attribution (CC BY) license (https:// creativecommons.org/licenses/by/ $4.0 /)$.

\begin{abstract}
The societal and economic benefits of ecosystem services are both immense and multifaceted. To holistically quantify the contribution of pollinators to agriculture requires measuring multiple indices of crop production beyond crop yield. Here, we conduct a field-based hand pollination experiment to measure the effects of self and outcross pollen on fiber yield and quality in conventionally managed cotton crops. First, we determine how different pollination treatments affect specific indices of fiber yield and fiber quality, including fiber length and fineness. Second, we investigate the suggested tradeoff between fiber yield and quality. We find that flowers receiving outcross pollen produce larger, heavier bolls than either self-crossed or non-crossed flowers. However, contrary to expectation, flowers of different treatments are indistinguishable in terms of fiber quality. Overall, we find that pollination treatment has no discernable effect on either fiber length or fiber fineness. Understanding the contribution of ecosystem services across multiple axes provides growers with information concerning potential tradeoffs or synergies, and offers insight into management decisions.
\end{abstract}

Keywords: economics; ecosystem service; fiber length; fiber fineness; Gossypium hirsutum

\section{Introduction}

Ecosystem services are processes through which natural systems support human life [1]. The societal and economic benefits of these services are both immense and multidimensional. Ecosystem services include, but are not limited to, climate regulation, biomass production, water supply and purification, pollination, and the provision of habitat [2-7]. Long recognized for their importance [8], ecosystem services are increasingly appreciated for their multi-faceted nature [9]. For example, while agricultural ecosystems are managed to optimize crop yield as food, fiber, or fuel, they also contribute a variety of supporting and regulating services, including soil fertility and habitat provision $[10,11]$. As a result, measuring the entirety of services provided by agricultural systems requires quantifying services beyond a single metric.

One particularly complex but vital ecosystem service is animal pollination. Pollination is critical for more than $80 \%$ of all flowering plant species $[8,12]$ and can impact fruit set across a variety of traits, including fruit size [13], shape [14], and chemical composition [15]. Roughly two-thirds of the world's most agriculturally important crops include cultivars that depend on animals to set maximum yield [16,17]. Although the positive effects of animal pollination have been shown in many food crops [18], the influence of pollination service on other economically and culturally important dimensions of agriculture, such as fuel and fiber crops, have received relatively less attention.

All plants experience tradeoffs in resource allocation, such as between competition and defense $[19,20]$ or between growth and reproduction [21,22]. Likewise, plants in agricultural ecosystems can experience tradeoffs between crop yield and crop quality. For 
example, increased kernel number in maize can lead to smaller kernel size [23,24], maximizing tomato yield may reduce fruit quality [25], and greater yearly yields in perennial crops may decrease crop longevity [26]. Tradeoffs may be especially evident in fiber crops, where indices of fiber quality and yield are known to vary widely within and between plants [27].

Fiber crops, including cotton, kenaf, jute, flax, and hemp, are grown for the production of fiber for textiles, cordage, and filling. A number of early studies on fiber crops documented a tradeoff between fiber quantity and quality, with those cultivars producing the most fiber also exhibiting the lowest quality [28-33]. Although much of the modern agricultural production of fiber is oriented toward increasing fiber quantity, a major component of profitability, these crops are also valued for the quality of their fiber [34]. Advances in spinning technology have created a demand for long, fine fibers in the textile industry. Longer fibers enable higher spinning speeds, whereas stronger fibers reduce breakage and allow for faster and more efficient processing, increasing the overall value of end products $[35,36]$.

Cotton is the most economically valuable fiber crop in the world. Prized for its softness and breathability, cotton is worth over USD 8 billion in the U.S. alone [37]. While the crop occupies only $2.1 \%$ of the world's arable land, it meets $27 \%$ of the world's textile needs [38,39]. Previous work in Upland cotton (Gossypium hirsutum L.) has shown that despite being a self-compatible species, pollination by insects can increase yield [40-42]. Specifically, hand pollination experiments revealed that cotton flowers receiving extra outcross pollen (from a different plant) produced significantly heavier bolls with more seeds than treatments receiving ambient pollination service or self-cross (from the same plant) pollen [41]. Though well-recognized as a major component of crop profitability, the relationship between pollination service and cotton fiber quality remains largely unquantified.

In this study, we investigated the potential for a pollination-mediated tradeoff between crop quantity and quality in the widespread and economically important cotton agroecosystem. First, we predicted that outcross pollination would contain a higher quantity of fiber than other groups, while the no-pollination treatment would contain a higher quality fiber than either the self or outcross treatments. Second, we examined the potential for resource investment tradeoffs across pollination treatments, and hypothesized that bolls with higher fiber quantity would have lower fiber quality. To examine these predictions, we measured cotton fiber quantity and quality produced in hand pollination experiments in 12 conventionally managed cotton fields across the Texas Gulf Coast, USA.

\section{Materials and Methods}

\subsection{Study System}

In 2014, we conducted hand pollination experiments in 12 cotton fields along the Gulf Coast of South Texas $(28.847913,-96.892975--28.303701$, and -97.381612, Figure 1) [41]. In addition to cotton, the South Texas region is also cultivated with sorghum, corn, and soybean (total agriculture is $55 \%$ of the landscape) [43]. The remainder of the region comprises cattle ranching, low-density developed areas, and natural areas. Cotton field sites were between 2 and $86 \mathrm{~km}$ apart, and were planted with conventionally managed cotton within three weeks of one another in late February 2014. Cotton was grown under similar management regimes (in terms of chemical applications, as described by growers) and planted with either Phytogen or Delta Pine cultivars.

\subsection{Hand Pollination Experiment}

To isolate the role of self and outcross pollen in fiber quantity and quality, we conducted a hand pollination experiment in each of the 12 cotton field sites. Early in the flowering season (13-15 June), 30 virgin flowers were covered with lightweight white organza bags that excluded pollinators and were randomly assigned to one of 3 treatments: closed (C), closed self-cross (CS), and closed outcross (CO), for a total of 10 flowers per treatment per site. Throughout anthesis, closed (C) flowers remained bagged, whereas closed self-cross flowers (CS) were bagged and supplemented with self-cross pollen from 
the same flower, and closed outcross (CO) flowers were bagged but received pollen from donor plants within a $10 \mathrm{~m}$ radius of the focal plant [41]. We consistently used flowers on nodes three through five and floral positions one and two as variation in floral position can alter resulting lint quantity and quality [44]. All pollination treatments were implemented between the hours 08:00 and 13:00, when cotton flowers are most receptive [40]. Cotton blooms remained covered until flowers were no longer receptive (2-3 days), after which bags were removed and bolls were left to mature for six weeks in the field. Once mature, bolls were hand-collected and processed.
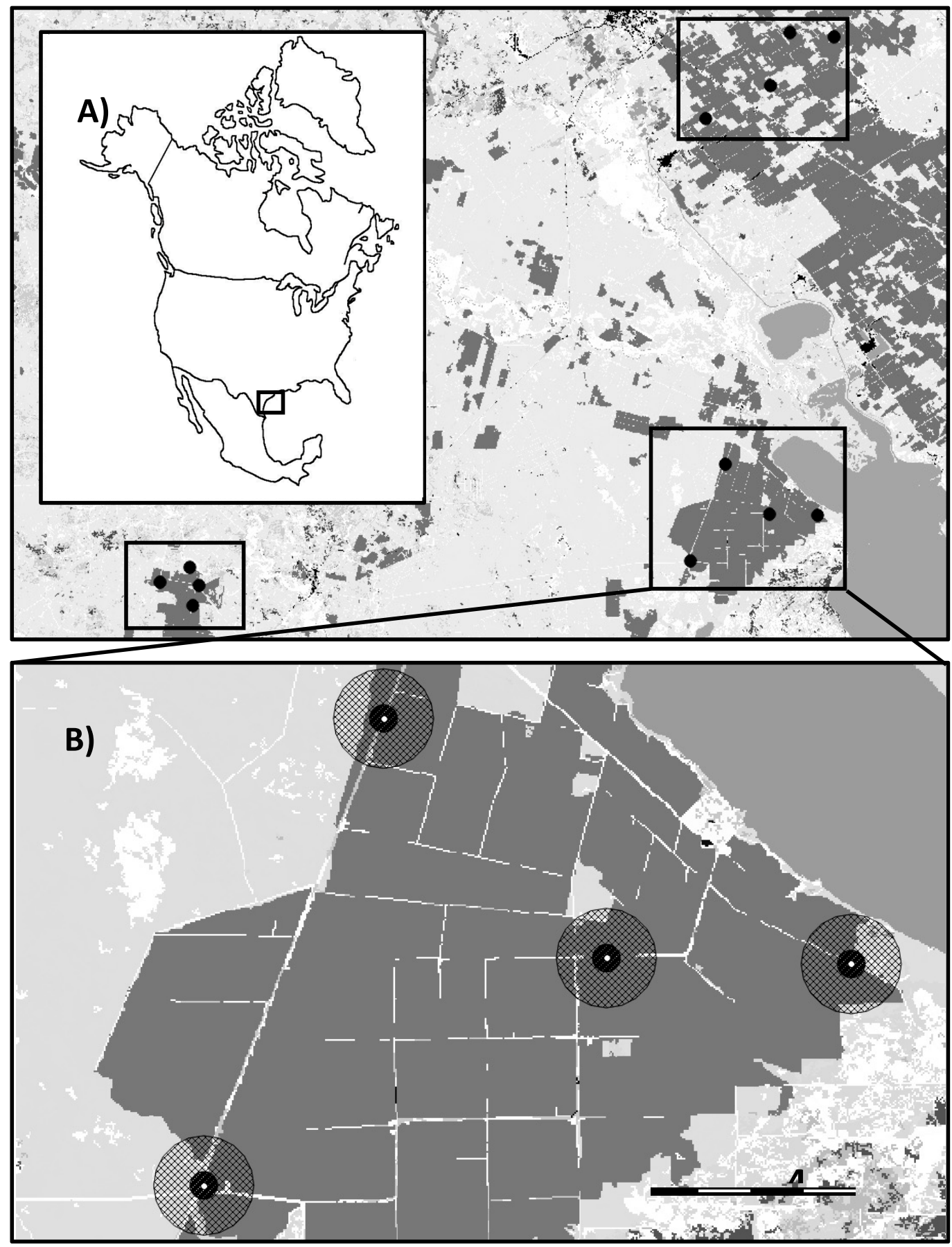

Figure 1. Map of study sites (inset) in North America highlighting the South Texas Gulf Coast study region, (A) map of 12 conventional cotton fields used as study sites in the hand pollination experiment, and (B) enlargement of four cotton field sites, shown as white dots, surrounded by a $2 \mathrm{~km}$ hatched circle shown for scale. 


\subsection{Fiber Processing}

To test the effects of hand pollination treatments, we measured four indices of fiber quantity and quality. To assess fiber quantity, seed cotton, which includes both lint and seeds, was manually removed from cotton bracts and measured as seed-cotton weight (grams) in the lab. The number of seeds per boll was estimated by counting the number of firm seeds per boll locule, or section, and multiplied by the number of locules per boll (3-5). To assess quality, fiber was first removed from seeds by hand and then analyzed via the Advanced Fiber Information System (AFIS) at the Cotton Phenomics Laboratory Fiber and Biopolymer Research Institute at Texas Tech University, which involves aero-mechanical fiber processing followed by electro-optical sensing and high-speed microprocessor-based computing [45]. Although the tests offer a wide range of quality indices, we focused on two of the most economically important: fiber length and fineness. Fiber length was measured as the average length of fiber in three randomly selected subsamples from each boll. Fiber fineness (weight per unit length), was measured as the average number of millitex (mTEX) for three randomly selected subsamples from each boll.

\subsection{Statistics}

To investigate our first hypothesis, concerning the relationship between pollination service and our four indices of cotton quantity and quality, we first used a Shapiro test to check for a normal distribution of response variables, followed by ANOVA and Tukey's HSD tests to determine if differences between hand pollination treatments $(C, C S$, and $\mathrm{CO}$ ) were significant at the alpha $=0.05$ level. Second, to investigate possible resource investment tradeoffs between cotton fiber quantity and quality, we used generalized linear mixed-effects models (GLMMs) using hand pollination treatment (C, CS, and CO) as a random effect, fiber quantity (seed-cotton weight and seed number/boll) as non-collinear explanatory fixed effects, and fiber quality (fiber length and fineness) as response variables. Models were investigated using the glmer function in the R Statistical package lme4 [46].

\section{Results}

\subsection{Fiber Processing}

Across all treatments, the seed-cotton weight ranged from $3.47 \mathrm{~g}$ to $7.0 \mathrm{~g}$ per boll (average $=5.2 \mathrm{~g}, \mathrm{SE}=0.03 \mathrm{~g}$ ). The number of seeds per boll ranged from 18 to 35 (average $=27$ seeds, $\mathrm{SE}=0.12$ seeds). Fiber length ranged from 2.2 to 3.04 in (Average $=2.8$ in, $\mathrm{SE}=1 \mathrm{in}$ ), and fiber fineness ranged from 165 to $224 \mathrm{mTEX}$ (Average $=200 \mathrm{mTEX}$, $\mathrm{SE}=0.32 \mathrm{mTEX})$.

\subsection{Statistics}

Investigating our first prediction concerning the effect of pollination service on cotton fiber quantity and quality, our ANOVA and Tukey tests indicated that flowers receiving outcross pollen produced heavier bolls with more seeds than flowers receiving either no pollen or self-cross pollen (Table 1, Figure 2a,b). However, pollination service had no effect on fiber quality in terms of fiber length or fineness (Table 1, Figure 2c,d).

Investigating our second prediction concerning the relationship between cotton fiber quantity and quality, our generalized mixed linear models found no tradeoff between measures of seed-cotton weight and fiber length (Table 2, Figure 3a), or between measures of seed-cotton weight and fiber fineness (mTEX) (Table 2, Figure 3b). Lastly, we also found no relationship between the number of seeds per boll and our two measures of fiber quality (Table 2). ANOVA and Tukey's HSD statistics were used to compare responses between treatments. Significance is shown with letters. 
Table 1. ANOVA models summarizing statistical differences of seed-cotton weight, seeds/boll, fiber length, and fiber fineness between hand pollination treatments (closed (C), closed self-cross (CS), and closed outcross (CO)).

\begin{tabular}{|c|c|c|c|c|c|}
\hline & Df & Sum Sq & Mean Sq & F Value & $p$ Value \\
\hline \multicolumn{6}{|l|}{ Seed-Cotton } \\
\hline \multicolumn{6}{|l|}{ Weight (g) } \\
\hline Treatment & 2 & 32.05 & 16.023 & 82.98 & $<0.001$ \\
\hline Residuals & 33 & 6.37 & 0.193 & & \\
\hline \multicolumn{6}{|l|}{ Seeds/Boll } \\
\hline Treatment & 2 & 368.2 & 184.09 & 22.75 & $<0.001$ \\
\hline Residuals & 33 & 267 & 8.09 & & \\
\hline \multicolumn{6}{|c|}{ Fiber Length (in) } \\
\hline Treatment & 2 & 1.25 & 0.627 & 0.196 & 0.823 \\
\hline Residuals & 33 & 105.73 & 3.204 & & \\
\hline \multicolumn{6}{|c|}{$\begin{array}{l}\text { Fiber Fineness } \\
\quad(\text { mTEX) }\end{array}$} \\
\hline Treatment & 2 & 28 & 14.19 & 0.096 & 0.909 \\
\hline Residuals & 33 & 4891 & 148.22 & & \\
\hline
\end{tabular}

(A)

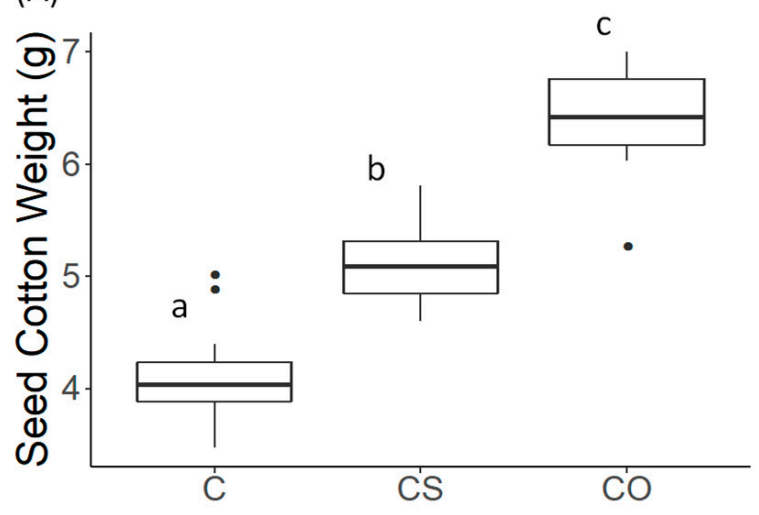

(C)

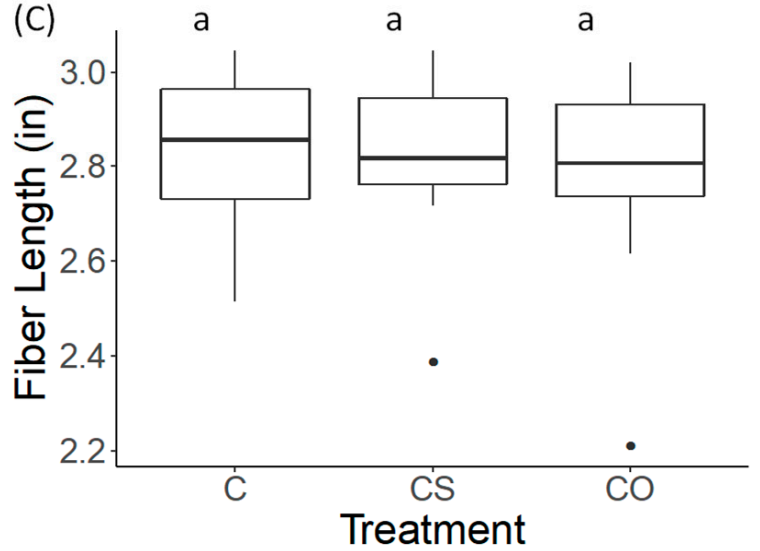

(B)

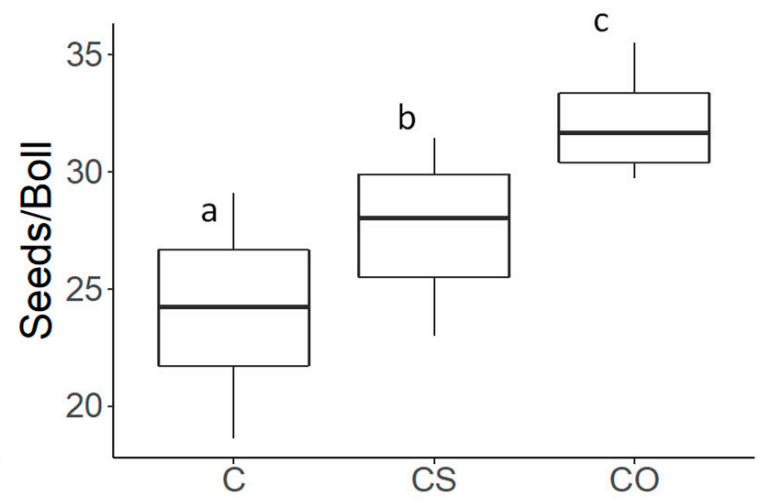

(D)

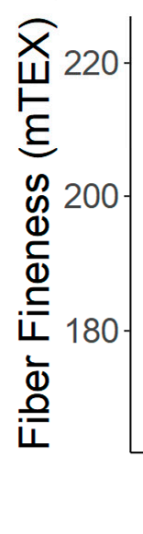

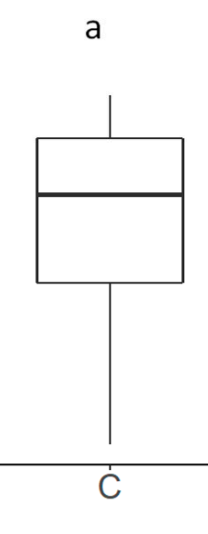

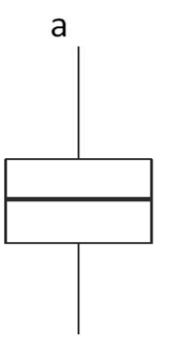

a

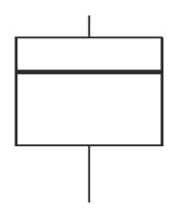

Figure 2. Boxplots comparing (A) seed-cotton weight (g), (B) number of seeds per boll, (C) fiber length (in), and (D) fiber fineness (mTEX) between three hand pollination treatments: closed (C), closed self-cross (CS), closed outcross (CO). Closed (C) flowers remained bagged with lightweight white organza bags throughout the flowering period, closed self-cross flowers (CS) were bagged but supplemented with self-cross pollen, and closed outcross (CO) flowers were bagged but received outcross pollen from three to five donor flowers in the vicinity. The central bar gives treatment mean, boxes indicate the 1st and 3rd quartiles, and closed circles show outliers. 
Table 2. Mixed linear models summarizing the relationship between fiber length and fiber fineness as a function of seed-cotton weight and number of seeds per boll. Model uses treatment (C, CS, CO) as a random effect, fiber quantity (seed-cotton weight and number of seeds per boll) as fixed effects, and fiber quality (fiber length and fineness) as response variables.

\begin{tabular}{cccccc}
\hline & Estimate & Std. Error & df & T Value & $p$ Value \\
\hline Fiber Length (in) & & & & & \\
$\quad$ Intercept & 1.111019 & 0.085632 & 33 & 12.974 & $<0.001$ \\
$\begin{array}{c}\text { Seed-cotton weight (g) } \\
\text { Number of seeds }\end{array}$ & -0.016764 & 0.021525 & 33 & -0.779 & 0.442 \\
$\quad$ per boll & 0.003094 & 0.005294 & 33 & 0.585 & 0.563 \\
\hline $\begin{array}{c}\text { Fiber Fineness } \\
\text { (mTEX) }\end{array}$ & & & & \\
$\quad$ Intercept & 204.9357 & 13.4956 & 33 & 15.185 & $<0.001$ \\
$\begin{array}{c}\text { Seed-cotton weight (g) } \\
\text { Number of seeds }\end{array}$ & 3.5867 & 3.3923 & 33 & 1.057 & 0.298 \\
per boll & -0.8429 & 0.8343 & 33 & -1.01 & 0.320 \\
\hline
\end{tabular}

(A)

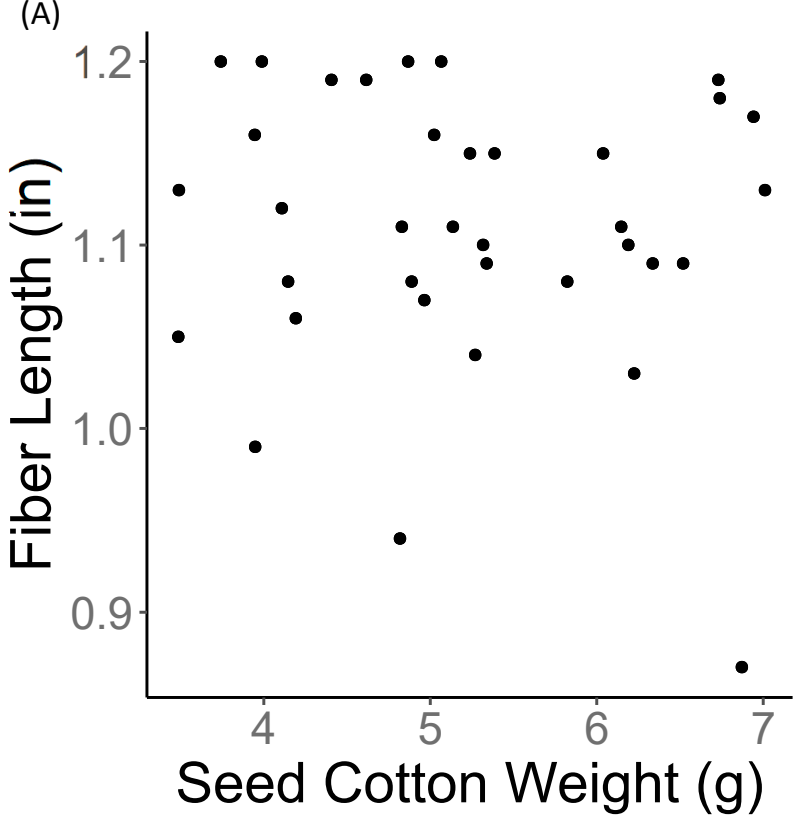

(B)

Figure 3. Correlation plots showing the lack of relationship between (A) seed-cotton weight (g) and fiber length (in) and (B) seed-cotton weight $(\mathrm{g})$ and fiber fineness (mTEX).

\section{Discussion}

In this study, we focused on the most valuable fiber crop in the world, cotton, and demonstrated that while pollination treatments had significant effects on seed-cotton weight and the number of seeds per boll, treatments had no effect on the indices of fiber quality (fiber length or fineness). Our results also demonstrate that fiber quality was not negatively correlated with fiber quantity in our system. In other words, we found no tradeoff between the measures of fiber quality and quantity, as we had initially predicted.

The impact of pollination on fiber quantity reflects the important economic contribution of pollinators in our system. We observed a 1.5-fold increase in seed-cotton weight between flowers excluded from outcross pollen (closed treatment) and those receiving an abundance of pollen from nearby plants (closed outcross treatment) [41]. As cotton pollen is known to be too heavy to move between flowers without an insect vector $[40,47]$, our results suggest that if insect pollinators were lost from the region entirely, growers would suffer a $36 \%$ decrease in seed-cotton produced by weight in the region. In South Texas, 
where cotton covers $\sim 10,000$ acres and is worth approximately USD 600 per acre, $36 \%$ of fiber loss would translate to USD 216/acre, or USD 2.1 million regionally [41].

Our study is among the first to investigate the influence of pollination on cotton fiber quality, of which we found no effect. Prior to marketing, fiber quality is evaluated and compared with industry standards. Fiber not meeting quality standard is subject to value deductions, which result in a reduced price paid per pound of lint or may even be deemed untenable and un-marketable. Potential losses in fiber quality can have devastating economic effects. As of 2020,15\% of cotton grown in the state of Texas is considered untenable due to low-quality fiber, an estimate slightly higher than the national average of $14 \%$ [48]. If methods were developed to increase fiber quality in this region, growers may see values increase by up to USD 90/acre, or USD 0.9 million regionally. Our finding that outcross pollen has no negative effect on fiber quality is a boon to minimizing losses due to low quality, untenable fiber.

Although classic studies of plant resource investment indicated that tradeoffs exist across fruit and seed traits in many crops, we did not document them here. Our findings indicate that tradeoffs between fiber quantity and quality may not be mediated by pollination, but may be mediated by other forces, such as water availability, nutrients, or irradiance [49]. Working in a relatively small region, with minimal geographic and abiotic variation, our sites were planted and hand pollinated within a few days of one another. As a result, our pollination treatments were exposed to nearly identical abiotic factors throughout their development. Treatment flowers were in similar node and floral positions on each plant [44], and because each boll was sampled three times at random for fiber quality, we accounted for variation in quality within each boll. As such, our experimental treatments were likely less influenced by biotic and abiotic factors. Ideally, future research may manipulate abiotic factors such as water availability, soil nutrients, and temperature, and would target whole-plant yield rather than the measure of a single boll per plant, as we did here. Our results may also reflect the superior breeding of cotton cultivars which have been developed since the 1970s and 1980s to improve fiber yield and increase consistency in fiber structure [50]. The modern cultivars used in our study are full-season varieties with high yield potential and have been specifically bred to have $90 \%$ fiber uniformity within boll and between plants.

Overall, we showed that the application of outcross pollen, while increasing seedcotton weight and the number of seeds per boll, had no detectable negative effects on indices of fiber quality (either length or fineness). This is particularly important information as the quality of cotton fiber affects the value of each pound of lint produced. Effective economic markets require accurate measures of both the quantity and quality of the goods and services being traded. Ideally, growers can manage for and measure the value of ecosystem services in terms of both the increased quantity of goods as well as potential changes in quality. These measures will allow growers to make well-informed management decisions to promote both crop quantity and quality, and will also provide opportunities for growers to consider and respond to changes of market value and demand.

Author Contributions: Conceptualization, S.C. and S.J., field work and formal analysis, S.C.; writing-original draft preparation, S.C.; writing-review and editing S.C. and S.J. Both authors have read and agreed to the published version of the manuscript.

Funding: S.C. and S.J. were funded by the Texas Parks and Wildlife Department, the Army Research Office, and the National Science Foundation.

Institutional Review Board Statement: Not applicable.

Informed Consent Statement: Not applicable.

Data Availability Statement: Data available upon request. 
Acknowledgments: Special thanks to the growers and landowners who allowed us to sample on their lands; without them, none of this work would have been possible. In addition, the help of the Cotton Phenomics Laboratory Fiber and Biopolymer Research Institute at Texas Tech University, Texas A\&M extension agents, crop consultants, and The Welder Wildlife Foundation, including Kathy Martin, Roy Parker, Stephen Biles, Lee Hutchins Jr., Kenneth Hanslik, Selma Glasscock, Nabil Nassari, Olivia Kost, and Terry Blankenship, was invaluable. Thanks to the Jha, Haddad, and Ricketts labs for the helpful feedback and support, as well as help in the field from Nicole Vojnovich, Alan Ritchie Jr., Sarah Cunningham, and Rebecca Ruppel.

Conflicts of Interest: The authors declare no conflict of interest.

\section{References}

1. Daily, G. Nature's Services: Societal Dependence on Natural Ecosystems; Island Press: Washington, DC, USA, 1997.

2. Bauhus, J.; van der Meer, P.; Kanninen, M. Ecosystem Goods and Services from Plantation Forests; Earthscan: New York, NY, USA, 2010.

3. Brockerhoff, E.G.; Jactel, H.; Parrotta, J.A.; Ferraz, S.F. Role of eucalypt and other planted forests in biodiversity conservation and the provision of biodiversity-related ecosystem services. For. Ecol. Manag. 2013, 301, 43-50. [CrossRef]

4. Decocq, G.; Andrieu, E.; Brunet, J.; Chabrerie, O.; De Frenne, P.; De Smedt, P.; Wulf, M. Ecosystem services from small forest patches in agricultural landscapes. Curr. For. Rep. 2016, 2, 30-44. [CrossRef]

5. $\quad$ Liang, J.; Crowther, T.W.; Picard, N.; Wiser, S.; Zhou, M.; Alberti, G.; Reich, P.B. Positive biodiversity-productivity relationship predominant in global forests. Science 2016, 354, 6309. [CrossRef] [PubMed]

6. Mori, A.S.; Lertzman, K.P.; Gustafsson, L. Biodiversity and ecosystem services in forest ecosystems: A research agenda for applied forest ecology. J. Appl. Ecol. 2017, 54, 12-27. [CrossRef]

7. Thompson, I.D.; Okabe, K.; Tylianakis, J.M.; Kumar, P.; Brockerhoff, E.G.; Schellhorn, N.A.; Nasi, R. Forest biodiversity and the delivery of ecosystem goods and services: Translating science into policy. BioScience 2011, 61, 972-981. [CrossRef]

8. Diaz, S.; Settele, J.; Brondízio, E.; Ngo, H.T.; Guèze, M.; Agard, J.; Zayas, C.N. Report of the Plenary of the Intergovernmental Science-Policy Platform on Biodiversity and Ecosystem Services on the work of its seventh session. In Proceedings of the Intergovernmental Science-Policy Platform on Biodiversity and Ecosystem Services (IPBES), Paris, France, 29 April 2020; Volume 7.

9. Small, N.; Munday, M.; Durance, I. The challenge of valuing ecosystem services that have no material benefits. Glob. Environ. Chang. 2017, 44, 57-67. [CrossRef]

10. Reid, W.V.; Mooney, H.A.; Cropper, A.; Capistrano, D.; Carpenter, S.R.; Chopra, K.; Zurek, M.B. Ecosystems and human well-being-Synthesis. In A Report of the Millennium Ecosystem Assessment; Island Press: Washington, DC, USA, 2005.

11. National Research Council. Status of Pollinators in North America; National Academies Press: Washington, DC, USA, 2007.

12. Ollerton, J.; Winfree, R.; Tarrant, S. How many flowering plants are pollinated by animals? Oikos 2011, 120, 321-326. [CrossRef]

13. Sapir, G.; Baras, Z.; Azmon, G.; Goldway, M.; Shafir, S.; Allouche, A.; Stern, R.A. Synergistic effects between bumblebees and honey bees in apple orchards increase cross pollination, seed number and fruit size. Sci. Hortic. 2017, 219, 107-117. [CrossRef]

14. Garratt, M.P.; Breeze, T.D.; Jenner, N.; Polce, C.; Biesmeijer, J.C.; Potts, S.G. Avoiding a bad apple: Insect pollination enhances fruit quality and economic value. Agric. Ecosyst. Environ. 2014, 184, 34-40. [CrossRef]

15. Bashir, M.A.; Alvi, A.M.; Khan, K.A.; Rehmani, M.I.A.; Ansari, M.J.; Atta, S.; Tariq, M. Role of pollination in yield and physicochemical properties of tomatoes (Lycopersicon esculentum). Saudi J. Biol. Sci. 2018, 25, 1291-1297. [CrossRef]

16. Gallai, N.; Salles, J.M.; Settele, J.; Vaissière, B.E. Economic valuation of the vulnerability of world agriculture confronted with pollinator decline. Ecol. Econ. 2009, 68, 810-821. [CrossRef]

17. Klein, A.M.; Vaissiere, B.E.; Cane, J.H.; Steffan-Dewenter, I.; Cunningham, S.A.; Kremen, C.; Tscharntke, T. Importance of pollinators in changing landscapes for world crops. Proc. R. Soc. Biol. 2007, 274, 303-313. [CrossRef]

18. Winfree, R.; Williams, N.M.; Gaines, H.; Ascher, J.S.; Kremen, C. Wild bee pollinators provide the majority of crop visitation across land-use gradients in New Jersey and Pennsylvania, USA. J. Appl. Ecol. 2008, 45, 793-802. [CrossRef]

19. Viola, D.V.; Mordecai, E.A.; Jaramillo, A.G.; Sistla, S.A.; Albertson, L.K.; Gosnell, J.S.; Levine, J.M. Competition-defense tradeoffs and the maintenance of plant diversity. Proc. Natl. Acad. Sci. USA 2010, 107, 17217-17222. [CrossRef]

20. Spoel, S.H.; Johnson, J.S.; Dong, X. Regulation of tradeoffs between plant defenses against pathogens with different lifestyles. Proc. Natl. Acad. Sci. USA 2007, 104, 18842-18847. [CrossRef]

21. Venable, D.L. Size-number trade-offs and the variation of seed size with plant resource status. Am. Nat. 1992, 140, 287-304. [CrossRef]

22. Roff, D.A. Trade-offs between growth and reproduction: An analysis of the quantitative genetic evidence. J. Evol. Biol. 2000, 13, 434-445. [CrossRef]

23. Schussler, J.R.; Westgate, M.E. Maize kernel set at low water potential: I. Sensitivity to reduced assimilates during early kernel growth. Crop. Sci. 1991, 31, 1189-1195. [CrossRef]

24. Gambín, B.L.; Borrás, L.; Otegui, M.E. Source-sink relations and kernel weight differences in maize temperate hybrids. Field Crop. Res. 2006, 95, 316-326. [CrossRef] 
25. Chen, J.; Kang, S.; Du, T.; Guo, P.; Qiu, R.; Chen, R.; Gu, F. Modeling relations of tomato yield and fruit quality with water deficit at different growth stages under greenhouse condition. Agric. Water Manag. 2014, 146, 131-148. [CrossRef]

26. González-Paleo, L.; Vilela, A.E.; Ravetta, D.A. Back to perennials: Does selection enhance tradeoffs between yield and longevity? Ind. Crop. Prod. 2016, 91, 272-278. [CrossRef]

27. Paterson, A.H.; Saranga, Y.; Menz, M.; Jiang, C.X.; Wright, R. QTL analysis of genotype $\times$ environment interactions affecting cotton fiber quality. Theor. Appl. Genet. 2003, 106, 384-396. [CrossRef] [PubMed]

28. Culp, T.W.; Harrell, D.C. Influence of lint percentage, boll size, and seed size on lint yield of upland cotton with high fiber strength. Crop Sci. 1975, 15, 741-745. [CrossRef]

29. Green, C.C.; Culp, T.W. Simultaneous improvement of yield, fiber quality, and yarn strength in Upland cotton. Crop Sci. 1990, 30, 66-69. [CrossRef]

30. Kerr, T. Yield Components in Cotton and Their Interrelations with Fiber Quality. 1966. Available online: www.cicr.org.in/isci/52/Paper_1.pdf (accessed on 25 March 2021).

31. Miller, P.A.; Williams, J.C.; Robinson, H.F.; Comstock, R.E. Estimates of genotypic and environmental variances and covariances in upland cotton and their implications in selection. J. Agron. 1958, 50, 126-131. [CrossRef]

32. Scholl, R.L.; Miller, P.A. Genetic association between yield and fiber strength in upland cotton. Crop. Sci. 1976, 16, 780-783. [CrossRef]

33. Worley, S.; Ramey, H.H.; Harrell, D.C.; Culp, T.W. Ontogenetic model of cotton yield. Crop. Sci. 1976, 16, 30-34. [CrossRef]

34. Freeland, T.B., Jr.; Pettigrew, B.; Thaxton, P.; Andrews, G.L. Agrometeorology and cotton production. Guide Agric. Meteorol. Pract. 2006, 10, 1-17.

35. Hasanbeigi, A.; Price, L. A technical review of emerging technologies for energy and water efficiency and pollution reduction in the textile industry. J. Clean. Prod. 2015, 95, 30-44. [CrossRef]

36. Kozlowski, R.M.; Mackiewicz-Talarczyk, M. Handbook of Natural Fibres: Volume 2: Processing and Applications; Woodhead Publishing: Camnbridge, MA, USA, 2020.

37. USDA ERS. Available online: https://usda.library.cornell.edu/concern/publications/mp48sc79x?locale=en (accessed on 25 March 2021).

38. Proto, M.; Supino, S.; Malandrino, O. Cotton: A flow cycle to exploit. Ind. Crop. Prod. 2000, 11, 173-178. [CrossRef]

39. Soth, J.; Grasser, C.; Salerno, R.; Thalmann, P. The Impact of Cotton on Freshwater Resources and Ecosystems: A Preliminary Synthesis; WWF Background Paper; WWF: Gland, Switzerland, 1999.

40. Free, J.B. Insect Pollination of Crops, 2nd ed.; Academic press: London, UK, 1993.

41. Cusser, S.; Neff, J.L.; Jha, S. Natural land cover drives pollinator abundance and richness, leading to reductions in pollen limitation in cotton agroecosystems. Agric. Ecosyst. Environ. 2016, 226, 33-42. [CrossRef]

42. Muhammad, W.; Ahmad, M.; Ahmad, I. Pollination behavior of cotton crop and its management. In Cotton Production and Uses; Springer: Singapore, 2020; pp. 163-175.

43. Han, W.; Yang, Z.; Di, L.; Mueller, R. CropScape: A Web service-based application for exploring and disseminating US conterminous geospatial cropland data products for decision support. Comput. Electron. Agric. 2012, 84, 111-123. [CrossRef]

44. Davidonis, G.H.; Johnson, A.S.; Landivar, J.A.; Fernandez, C.J. Cotton fiber quality is related to boll location and planting date. J. Agron. 2004, 96, 42-47. [CrossRef]

45. Davidonis, G.; Hinojosa, O. Influence of seed location on cotton fiber development in planta and in vitro. Plant Sci. 1994, 103, 107-113. [CrossRef]

46. Bates, D.; Maechler, M.; Bolker, B.; Walker, S. lme4: Linear mixed-effects models using Eigen and S4. R Packag. Vers. 2014, 1, 1-23.

47. Rhodes, J. Cotton pollination by honeybees. Aust. J. Exp. Agric. 2002, 42, 513-518. [CrossRef]

48. USDA. Statistics by state. US Department of Agriculture, National Agricultural Statistics Service, Washington DC. Available online: https:/ / www.nass.usda.gov/Statistics_by_State/ (accessed on 25 March 2021).

49. Bradow, J.M.; Danidonis, G.H. Quantitation of fiber quality and the cotton production-processing interface: A physiologist's perspective. J. Cotton Sci. 2000, 4, 34-64.

50. Culp, T.W.; Harrell, D.C.; Kerr, T. Some genetic implications in the transfer of high fiber strength genes to upland cotton. Crop Sci. 1979, 19, 481-484. [CrossRef] 